\title{
VERTICAL CEPHALOMETRIC CHANGES AFTER TREATMENT OF CLASS II DIVISION 1 MALOCCLUSION
}

\author{
ALTERAÇÕES CEFALOMÉTRICAS VERTICAIS APÓS O TRATAMENTO DA MÁ OCLUSÃO DE CLASSE II, $1^{a}$ DIVISÃO
}

\author{
Maurício Souto* \\ Priscilla Midori Maeda* \\ Helio Scavone-Junior \\ Rívea Inês Ferreira \\ Flávio Vellini-Ferreira
}

\begin{abstract}
Introduction - The aim of this study is to evaluate the vertical cephalometric alterations in Brazilian females with Class II Division 1 malocclusion, treated orthodontically with and without premolar extraction. Methods - Seventy-eight lateral cephalometric radiographs of 39 white Brazilian females were assessed in the pre- and posttreatment stages. The sample was divided into two groups: with extraction of the four first premolars $(\mathrm{n}=14)$ and without extractions $(\mathrm{n}=25)$. The cephalometric measurements investigated were as follows: Is-St, Sn-St, Is-PP, Ms-PP, Ei, SN.GoMe, SN.Gn, SN.PP, PP.GoMe and PP.MsIs. Measurements relative to the pre- and posttreatment stages were compared by the paired Student's- $t$ test. The studied groups were compared using ANOVA with the Scheffé test. Results - In the group treated with extractions, there was a statistically significant increase in the following measurements: Is-PP, Ms-PP and SN.PP. On the other hand, in the group treated without extractions, Sn-St, Is-PP, Ms-PP and SN.Gn were significantly increased. Furthermore, there was a significant reduction in PP.MsIs. When comparing the studied groups, significant difference was found only for SN.PP, which was greater in the group treated with extractions. Conclusion - The results showed that orthodontic treatment with extraction of the four premolars was associated to clockwise rotation of the palatine plane.
\end{abstract}

DESCRIPTORS: Malocclusion, Angle Class II - Cephalometry - Orhodontics, corrective.

\section{RESUMO}

Introdução - O objetivo deste estudo é avaliar as alteraçóes cefalométricas verticais em mulheres brasileiras com má oclusão de Classe II, $1^{\text {a }}$ Divisão, tratadas ortodonticamente com e sem exodontia de pré-molares. Métodos - Foram analisadas 78 telerradiografias cefalométricas em norma lateral, nas fases pré e pós-tratamento, de 39 mulheres leucodermas. A amostra foi dividida em dois grupos: com exodontia dos quatro primeiros pré-molares $(\mathrm{n}=14)$ e sem exodontias $(\mathrm{n}=25)$. As medidas cefalométricas investigadas foram: Is-St, Sn-St, Is-PP, Ms-PP, Ei, SN.GoMe, SN.Gn, SN.PP, PP.GoMe e PP.MsIs. As medidas relativas às fases pré e pós-tratamento foram comparadas pelo teste $\mathrm{t}$ de Student pareado. Os grupos estudados foram comparados empregando-se ANOVA com teste Scheffé. Resultados - No grupo tratado com exodontias, ocorreu um aumento estatisticamente significante nas seguintes medidas: Is-PP, Ms-PP e SN.PP. Por outro lado, no grupo tratado sem exodontias, houve aumento significativo de: Sn-St, Is-PP, Ms-PP e SN.Gn. Em adiçấo, houve redução significativa de PP.MsIs. Comparando-se os grupos estudados, verificou-se diferença significativa apenas para SN.PP, que foi maior no grupo tratado com exodontias. Conclusão - Os resultados evidenciaram que o tratamento ortodôntico com exodontia dos quatro pré-molares foi associado a uma rotaçáo do plano palatino em sentido horário.

DESCRITORES: Má oclusão de Angle Classe II - Cefalometria - Ortodontia corretiva

\footnotetext{
* Research Fellow, Department of Pediatric Dentistry and Orthodontics, University of São Paulo City (UNICID).

" Orthodontist and Research Fellow, Vellini Institute.

"* Associate Professors, Department of Pediatric Dentistry and Orthodontics, University of São Paulo City (UNICID).

*.*. Professor and Chairman, Department of Pediatric Dentistry and Orthodontics, University of São Paulo City (UNICID) and Director, Vellini Institute.
} 
Souto M, Maeda PM, Scavone-Junior H, Ferreira RI, Vellini-Ferreira F. Vertical cephalometric changes after treatment of Class II division 1 malocclusion. Revista de Odontologia da Universidade Cidade de São Paulo 2008 jan-abr; 20(1):6-13

\section{INTRODUCTION}

Vertical alterations that occur in the maxillary incisors during orthodontic treatment of Class II Division 1 malocclusion are of great clinical importance, since the extrusion or intrusion of these teeth may influence the smile esthetics. The incisolabial relationship may undergo appreciable changes after treatment, not only as a result of the craniofacial growth and development, but also because of orthodontic procedures adopted, such as extraction, retraction of the maxillary incisors, as well as the use of intermaxillary elastics and extraoral appliances.

Facial esthetics enhancement has been considered an orthodontic treatment goal together with establishing satisfactory occlusion (Brant and Siqueira ${ }^{1}, 2006$; Subtelny ${ }^{14}$, 1961; Tadic and Woods ${ }^{15}$, 2007). The positioning of the upper lip in relation to the incisal edge of the maxillary incisors has clinical relevance (Burstone $\left.^{2}, 1959\right)$ and represents a fundamental aspect to be analyzed, in order to ensure an esthetically harmonious smile (Burstone ${ }^{3}$, 1967; Scavone-Junior et al. ${ }^{12}$, 2003; Subtelny ${ }^{14}$, 1961; Uchiyama et al. $\left.{ }^{17}, 2006\right)$. In addition, several other orthodontic vertical changes may be implicated in the smile esthetics, for instance: alterations in the position of the maxillary molars, inclination of the occlusal plane and reorientation of the craniofacial complex growth direction. In a patient presenting a dolichofacial growth pattern, much care should be taken not to produce undesirable tooth extrusion.

Vertical cephalometric alterations due to orthodontic treatment have been increasingly emphasized (Machado et al. $\left.{ }^{7}, 2005\right)$. For this reason, cephalometric studies may provide valid scientific contributions to the understanding and estimation of possible vertical changes associated with orthodontic treatment, particularly concerning the incisolabial relationship. Nevertheless, many investigations have focused predominantly on the horizontal relationships. A relative scarcity of information with reference to vertical components in young Brazilians is observed.

Thus, the aim of the present study was to carry out a comparative assessment of the vertical cephalometric changes in white Brazilian females with Class II Division 1 malocclusion, treated orthodontically with and without premolar extractions. The null hypothesis stated no differences in the vertical measurements analyzed between the two treatment modalities.

\section{METHODS}

This study is in agreement with Resolution 196/96 from the National Health Council/Health Department (Brazil).

\section{Sample Selection}

The sample was collected from the archives of the Department of Pediatric Dentistry and Orthodontics, University of São Paulo City - UNICID. Seventy-eight standardized lateral cephalometric radiographs of 39 white Brazilian females in the pre- and posttreatment stages were selected, according to the following inclusion criteria: (1) Angle Class II, Division 1 malocclusion diagnosed, (2) permanent dentition, (3) absence of dental mutilations and posterior crossbites, (4) orthodontic treatment by the modified Edgewise technique accomplished, and (5) satisfactory end results assessed in good quality initial and final lateral cephalometric radiographs.

Subsequently, the sample was assigned to two groups. The group treated with extraction of the four first premolars comprised 14 patients with mean age of 12 years and 8 months, at the beginning of orthodontic treatment, and 16 years and 9 months at the end. The group treated without extractions, consisted of 25 patients with mean age of 12 years and 3 months at the initial stage, and 15 years and 3 months at the end of orthodontic treatment.

\section{Cephalometric Assessment}

Cephalometric tracings were manually performed by a calibrated examiner on transparent acetate paper. The anatomic drawing included: frontal and nasal bones, sella turcica, outlines of the orbital cavities, external acoustic meatus, pterygomaxillary fissure, maxilla, mandible, maxillary and mandibular central incisors, maxillary and mandibular first molars and the soft-tissue profile, starting above the glabella and prolonged up to the mandibular region, with chin outline. The following cephalometric landmarks were selected: subnasal $(\mathrm{Sn})$, stomium $(\mathrm{St})$, stomium superius (Sts), stomium inferius (Sti), incisal edge of the maxillary central incisor (Is), mesiobuccal cusp of the maxillary first molar $(\mathrm{Ms})$, sella $(\mathrm{S})$, nasion $(\mathrm{N})$, anterior nasal spine (ANS), posterior nasal spine (PNS), menton $(\mathrm{Me})$, gonion $(\mathrm{Go})$ and gnathion $(\mathrm{Gn})$. The cephalometric lines and planes comprised: GoMe (mandibular plane), PP or ANS-PNS (palatine plane), MsIs (maxillary occlusal plane), SN (sella-nasion line, which represents the anterior cranial 
Souto M, Maeda PM, Scavone-Junior H, Ferreira RI, Vellini-Ferreira F. Vertical cephalometric changes after treatment of Class II division 1 malocclusion. Revista de Odontologia da Universidade Cidade de São Paulo 2008 jan-abr; 20(1):6-13

base) and SGn (sella-gnathion line, which represents the craniofacial growth vector). The linear and angular cephalometric variables analyzed are shown in Figures 1 and 2 , respectively.

To increase the precision and reliability of the cephalometric measurements used, the assessments were performed twice. A two-week interval was allowed to elapse between the first and second examination. The mean values obtained after two cephalometric assessments were used as the final values for statistical analyses, because they were considered the best estimates of the real values, as recommended by Martins et al. ${ }^{9}$ (1995). For cases in which differences greater than $1 \mathrm{~mm}$ or 1 degree between the two measurements were found, a third tracing was done with the respective measurements. Next, the tracing that presented the most discrepant values was excluded.

\section{Statistical Analyses}

In the two studied groups, the cephalometric measurements obtained before and after orthodontic treatment were compared using the Student's- $t$ test $(\alpha=0.05)$. For the assessment of alterations in the cephalometric variables between the pre- and posttreatment stages, Analysis of Variance (ANOVA) and Scheffé test were used.

\section{RESULTS}

Tables 1 and 2 present the results of the pre- and posttreatment comparative analyses for the groups treated with and without extractions, respectively. The variables Is-PP, Ms-PP and SN.PP showed a statistically significant increase in the group with extractions $(\mathrm{p}<0.01)$. In the group without extractions, the variables $\mathrm{Sn}-\mathrm{St}$, IsPP, Ms-PP and SN.Gn were observed to be significantly greater after orthodontic treatment $(\mathrm{p}<0.01)$, whereas the mean value related to the PP.MsIs angle demonstrated a mean reduction of $1.48^{\circ}$. This measurement reveals the divergence between the palatine and maxillary occlusal planes.

Remarkably, in the group without extractions, the linear measurement related to the upper lip height (Sn-

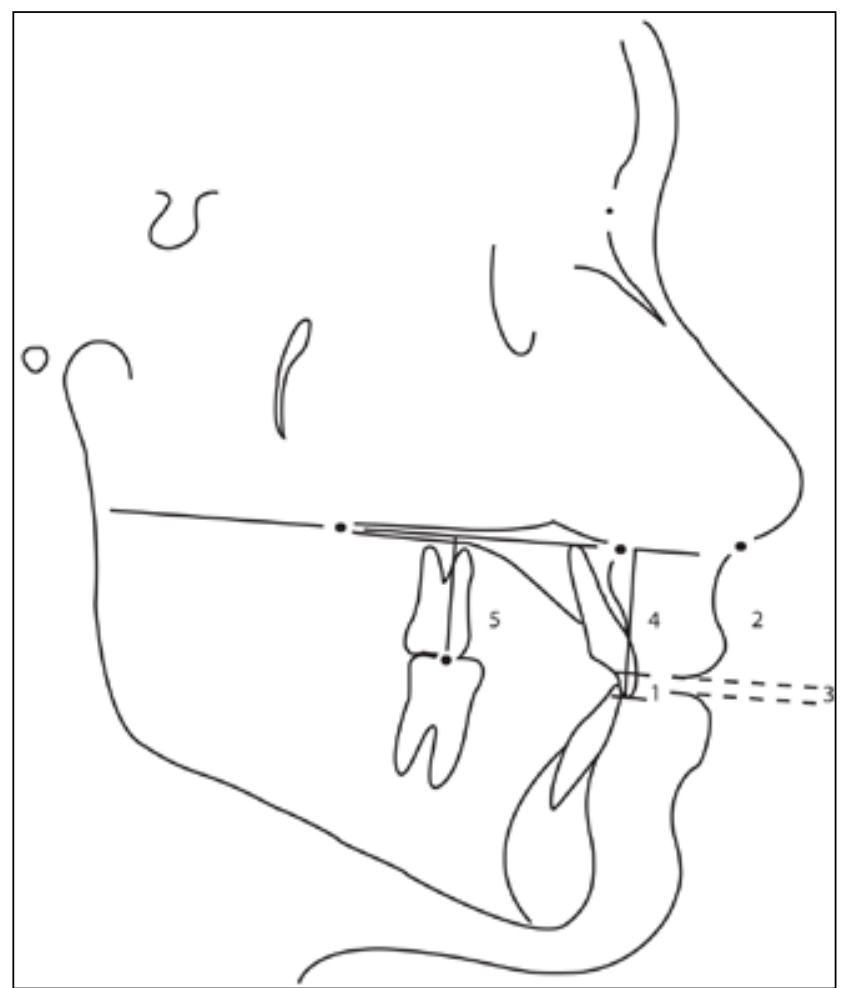

Figure 1 - Linear cephalometric measurements. 1: Is-St; 2: upper lip height (Sn-Sts); 3: space between lips (StsSti); 4: vertical position of the maxillary central incisor (Is-PP) and 5: vertical position of the maxillary first molar (Ms-PP).

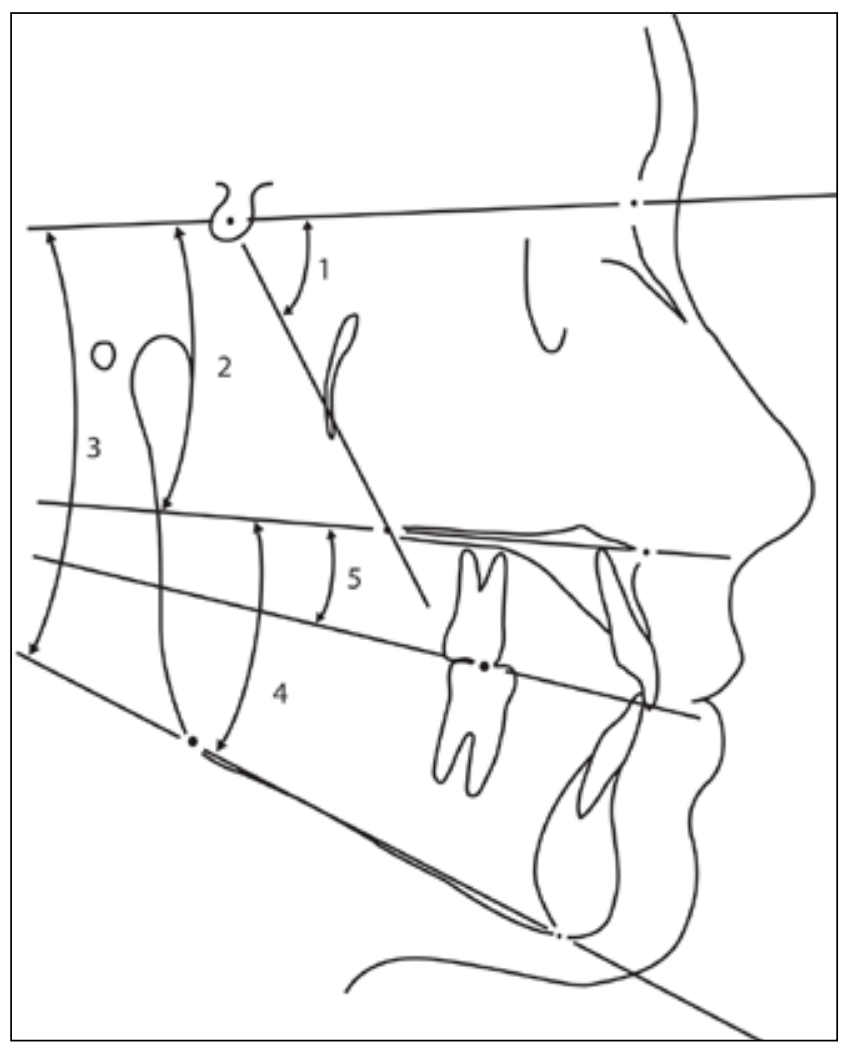

Figure 2 - Angular cephalometric measurements. 1: SN.Gn angle; 2: SN.PP angle; 3: SN.GoMe angle; 4: PP.GoMe angle and 5: PP.MsIs angle. 
Souto M, Maeda PM, Scavone-Junior H, Ferreira RI, Vellini-Ferreira F. Vertical cephalometric changes after treatment of Class II division 1 malocclusion. Revista de Odontologia da Universidade Cidade de São Paulo 2008 jan-abr; 20(1):6-13

Table 1 - Means (x) and standard deviations (s.d.), minimum values (min.v.) and maximum values (max.v.) of vertical cephalometric variables (linear and angular), for the group with extractions, in the pre-and posttreatment stages, compared using the Student's-t test.

\begin{tabular}{|c|c|c|c|c|c|c|c|c|c|c|c|c|c|c|c|}
\hline \multicolumn{16}{|c|}{ Group with extractions } \\
\hline \multicolumn{5}{|c|}{ pretreatment } & \multicolumn{4}{|c|}{ posttreatment } & \multicolumn{4}{|c|}{ variation } & \multicolumn{3}{|c|}{ " $\mathrm{t}$ " test } \\
\hline variables & $\mathrm{x}$ & s.d. & min.v. & max.v. & $\mathrm{x}$ & s.d. & min.v. & max.v. & $\mathrm{x}$ & s.d. & min.v. & max.v. & $\mathrm{t}$ & $\mathrm{p}$ & $S$ \\
\hline Is - St (mm) & 4.28 & 2 & 0.5 & 9 & 4.5 & 1.9 & 1.75 & 9.5 & 0.21 & 2 & -4.8 & 3.25 & 0.39 & 0.69 & N.S. \\
\hline Sn $-S t(m m)$ & 22.9 & 2.5 & 18 & 27.5 & 23.1 & 2.3 & 18 & 26.8 & 0.16 & 1.6 & -2.5 & 2.75 & 0.38 & 0.7 & N.S. \\
\hline Is - PP (mm) & 29.9 & 2.2 & 27.3 & 35.8 & 30.6 & 2.4 & 28.3 & 37 & 0.71 & 0.9 & -1.3 & 2 & 3.03 & 0 & $* *$ \\
\hline $\begin{array}{c}\text { Ms - } \\
\mathrm{PP}(\mathrm{mm})\end{array}$ & 23.6 & 1.7 & 21 & 27.3 & 25.6 & 1.8 & 22.5 & 29.8 & 1.94 & 0.7 & 0.75 & 3 & 10.7 & 0 & $* *$ \\
\hline $\begin{array}{c}\text { Sts - Sti } \\
(\mathrm{mm})\end{array}$ & 1.01 & 2.5 & 0 & 9.5 & 1.01 & 2.3 & 0 & 8.25 & 0 & 2.6 & -6.3 & 6.75 & 1.32 & 0.20 & N.S. \\
\hline $\begin{array}{l}\text { SN.GoMe } \\
(\text { o })\end{array}$ & 38.2 & 5 & 30.8 & 49.8 & 38.5 & 2.8 & 29 & 51 & 0.3 & 2 & -3 & 3.75 & 0.57 & 0.57 & N.S. \\
\hline SN.Gn (o) & 70.8 & 3.3 & 66.3 & 78.5 & 71.8 & 3.9 & 66 & 79 & 0.91 & 1.7 & -1.3 & 4 & 2 & 0.06 & N.S. \\
\hline SN.PP (o) & 7.73 & 2.6 & 2 & 12 & 9.21 & 2.1 & 6 & 14 & 1.48 & 1.2 & -0.5 & 4 & 4.65 & 0 & $* *$ \\
\hline PP.GoMe (o) & 30 & 5.2 & 21.3 & 39.8 & 29.1 & 6 & 18 & 40.3 & -0.9 & 1.6 & -4.3 & 1.75 & 2.03 & 0.06 & N.S. \\
\hline PP. MsIs (o) & 11.1 & 3.1 & 6.75 & 17.8 & 10.6 & 3.4 & 6.5 & 17.5 & -0.7 & 2.6 & -4.5 & 4 & 0.99 & 0.34 & N.S. \\
\hline
\end{tabular}

Statistical Significance: * $\mathrm{p}<0.05$ "t" critical : $2.160 \quad{ }^{* *} \mathrm{p}<0.01$ "t" critical : $3.012 \quad$ N.S. - Not significant

Table 2 - Means (x) and standard deviations (s.d.), minimum values (min.v.) and maximum values (max.v.) of vertical cephalometric variables (linear and angular), for the group without extractions, in the pre-and posttreatment stages, compared using the Student's-t test.

\begin{tabular}{|c|c|c|c|c|c|c|c|c|c|c|c|c|c|c|c|}
\hline \multicolumn{16}{|c|}{ Group without extractions } \\
\hline & \multicolumn{4}{|c|}{ pretreatment } & \multicolumn{4}{|c|}{ posttreatment } & \multicolumn{4}{|c|}{ variation } & \multicolumn{3}{|c|}{ "t" test } \\
\hline variables & $\mathrm{x}$ & s.d. & min.v. & max.v. & $\mathrm{x}$ & s.d. & min.v. & max.v. & $\mathrm{x}$ & s.d. & min.v. & max.v. & $\mathrm{t}$ & $\mathrm{p}$ & $S$ \\
\hline $\begin{array}{l}\text { Is - St } \\
(\mathrm{mm})\end{array}$ & 4.13 & 1.9 & 0.5 & 8.25 & 4.1 & 1.31 & 2 & 6.75 & -0.03 & 1.5 & -2 & 3.25 & 0.1 & 0.9 & N.S \\
\hline $\begin{array}{c}S n-S t \\
(m m)\end{array}$ & 21.4 & 1.8 & 16.8 & 25.3 & 22.2 & 1.55 & 20 & 25.8 & 0.75 & 1.3 & -2 & 4 & 2.9 & 0 & $* *$ \\
\hline $\begin{array}{c}\mathrm{Is}- \\
\mathrm{PP}(\mathrm{mm})\end{array}$ & 27.7 & 2.8 & 23 & 32.8 & 28.9 & 2.67 & 25 & 34.8 & 1.26 & 1.4 & -1.5 & 4.5 & 4.5 & 0 & $* *$ \\
\hline $\begin{array}{c}\text { Ms - PP } \\
(\mathrm{mm})\end{array}$ & 21.3 & 2.5 & 17.3 & 26.5 & 23.6 & 2.14 & 20 & 28.8 & 2.17 & 1.8 & -1.5 & 5 & 6.35 & 0 & $* *$ \\
\hline $\begin{array}{c}\text { Sts - Sti } \\
(\mathrm{mm})\end{array}$ & 1.11 & 2.3 & 0 & 8 & 0.38 & 0.93 & 0 & 3.5 & -0.75 & 2.5 & -7.5 & 3 & 1.5 & 0.1 & N.S \\
\hline $\begin{array}{l}\text { SN.GoMe } \\
(\text { o })\end{array}$ & 36.6 & 5.9 & 25 & 50.5 & 36.7 & 6.2 & 23 & 50.5 & 0.1 & 1.2 & -2 & 2.25 & 0.4 & 0.7 & N.S \\
\hline SN.Gn (o) & 69.4 & 4.2 & 61 & 78 & 70 & 4.76 & 59 & 78.3 & 0.65 & 1.2 & -2 & 3.5 & 2.8 & 0 & $* *$ \\
\hline SN.PP (o) & 8.35 & 3.9 & -0.75 & 14.3 & 8.62 & 4.27 & -3.5 & 14.8 & 0.28 & 1.5 & -4 & 3.25 & 0.9 & 0.4 & N.S \\
\hline $\begin{array}{l}\text { PP.GoMe } \\
\quad\left({ }^{\circ}\right)\end{array}$ & 28.4 & 4.6 & 20 & 40.3 & 28.1 & 5.2 & 20 & 42 & -0.31 & 1.3 & -2.8 & 2.75 & 1.2 & 0.3 & N.S \\
\hline $\begin{array}{c}\text { PP.MsIs } \\
(\mathrm{o})\end{array}$ & 11.4 & 3 & 6.5 & 20 & 9.95 & 3.42 & 4 & 19 & -1.48 & 2.2 & -5 & 2.5 & 3.57 & 0 & $* *$ \\
\hline
\end{tabular}

Statistical Significance: * $\mathrm{p}<0.05$ "t" critical : $2.064 \quad{ }^{* *} \mathrm{p}<0.01$ "t" critical : $2.797 \quad$ N.S. - Not significant 
Souto M, Maeda PM, Scavone-Junior H, Ferreira RI, Vellini-Ferreira F. Vertical cephalometric changes after treatment of Class II division 1 malocclusion. Revista de Odontologia da Universidade Cidade de São Paulo 2008 jan-abr; 20(1):6-13

Table 3 - Analysis of statistical significance for the intergroup variations, in the pre-and posttreatment stages.

\begin{tabular}{|c|c|c|c|c|c|c|c|c|}
\hline \multicolumn{9}{|c|}{ Intergroup Variations } \\
\hline & \multirow{2}{*}{\multicolumn{2}{|c|}{$\begin{array}{l}\text { group with extractions } \\
\text { pre- and posttreat. varia- } \\
\text { tions }\end{array}$}} & \multirow{2}{*}{\multicolumn{2}{|c|}{$\begin{array}{l}\text { group without extractions } \\
\text { pre- and posttreat. varia- } \\
\text { tions }\end{array}$}} & \multicolumn{4}{|c|}{ Intergroup Analysis of Variance } \\
\hline & & & & & & & & \\
\hline Variables & $\mathrm{x}$ & s.d. & $\mathrm{x}$ & s.d. & $\begin{array}{l}\text { Diff. in } \\
\text { Means }\end{array}$ & $\mathrm{F}$ & $\mathrm{p}$ & $S$ \\
\hline Is - St (mm) & 0.21 & 2.02 & -0.03 & 1.51 & 0.24 & 0.18 & 0.67 & N.S. \\
\hline $\mathrm{Sn}-\mathrm{St}(\mathrm{mm})$ & 0.16 & 1.57 & 0.75 & 1.27 & -0.58 & 1.61 & 0.21 & N.S. \\
\hline Is - PP (mm) & 0.71 & 0.88 & 1.26 & 1.38 & -0.54 & 1.75 & 0.19 & N.S. \\
\hline $\mathrm{Ms}-\mathrm{PP}(\mathrm{mm})$ & 1.94 & 0.68 & 2.17 & 1.75 & -0.24 & 0.25 & 0.62 & N.S. \\
\hline Sts - Sti $(\mathrm{mm})$ & 0 & 2.48 & -0.75 & 2.46 & 0.75 & 3.88 & 0.05 & N.S. \\
\hline SN.GoMe (o) & 0.3 & 1.98 & 0.1 & 1.2 & 0.2 & 0.15 & 0.69 & N.S. \\
\hline SN.Gn (o) & 0.91 & 1.7 & 0.65 & 1.15 & 0.26 & 0.32 & 0.57 & N.S. \\
\hline SN.PP (o) & 1.48 & 1.19 & 0.28 & 1.47 & 1.2 & 6.77 & 0.01 & $*$ \\
\hline PP.GoMe (o) & -0.89 & 1.64 & -0.31 & 1.31 & -0.58 & 1.47 & 0.23 & N.S. \\
\hline PP.MsIs (o) & -0.69 & 2.63 & -1.52 & 2.12 & 0.82 & 1.13 & 0.29 & N.S. \\
\hline
\end{tabular}

Statistical Significance: * $\mathrm{p}<0.05 \quad$ "f" critical : $4.110 \quad{ }^{* *} \mathrm{p}<0.01$ "f" critical : $7.388 \quad$ N.S. - Not significant

St) showed a mean increase of $0.75 \mathrm{~mm}$. The vertical distance, in millimeters, from the incisal edge of the maxillary incisor to the palatine plane (Is-PP) showed mean increases of $0.71 \mathrm{~mm}$ and $1.26 \mathrm{~mm}$ in the groups with and without extractions, respectively. The vertical distance between the mesiobuccal cusp of the maxillary first molar and the palatine plane (Ms-PP) increased, on average, $1.94 \mathrm{~mm}$ and $2.17 \mathrm{~mm}$ in the groups with and without extractions, respectively.

The angular measurement suitable for the evaluation of craniofacial growth direction (SN.Gn) significantly increased by $0.65^{\circ}$, on average, in the group without extractions. However, when analyzing the two studied groups (Table 3), it was found that this angle showed a slightly higher mean increase $\left(0.91^{\circ}\right)$ in the group with premolar extractions, which presumably should not be associated with marked modifications in the craniofacial growth direction.

The angle that provides an appraisal of the divergence between the palatine plane and the anterior cranial base (SN.PP) increased by $1.48^{\circ}$, on average, in the group with extractions, indicating a slight clockwise rotation of the palatine plane.

According to Table 3, of all the variables assessed, SN.PP presented a significantly greater increase in the group with extractions. The difference between the mean values calculated for the studied groups was of $1.2^{\circ}(\mathrm{p}<0.05)$.

\section{DISCUSSION}

Actually, orthodontic treatment may change the relationship between maxillary incisors and the upper lip, as well as the relative position of the molars. Hence, orthodontic treatment may be implicated in the alterations of the palatine and mandibular planes' inclination, as a result of growth direction change itself and extrusion or intrusion movements of the posterior teeth. In a patient presenting a dolichofacial growth pattern, every care should be taken not to promote undue extrusions, which, in turn, are associated with an increase in the vertical dimensions and worsening of the relationship among lips, teeth and bony structures. In this context, the present research endeavored to demonstrate, despite some methodological limitations, two orthodontic therapeutic modalities that could be related to several vertical alterations.

In order to assess dentofacial modifications in orthodontically treated patients and compare them with facial changes that occur naturally during the craniofacial growth process, the values registered by Scavone-Junior ${ }^{13}$ (1996) and Martins et al. ${ }^{8}$ (1998) were used as base line. This sample comprised only females, since the available number of cases corresponding to male patients was reduced. Some authors, such as Peck et al. ${ }^{10}$ (1992), conducted similar studies, but used clinical measurements obtained directly from the patients' face. In this investigation, cephalometric analysis was used, considering 
Souto M, Maeda PM, Scavone-Junior H, Ferreira RI, Vellini-Ferreira F. Vertical cephalometric changes after treatment of Class II division 1 malocclusion. Revista de Odontologia da Universidade Cidade de São Paulo 2008 jan-abr; 20(1):6-13

that it was easier to select the required material (initial and final lateral cephalometric radiographs).

When analyzing the linear distance between the incisal edge of the maxillary incisor and the lower boundary of the upper lip (Is-St), in the group with premolar extractions (Table 1), it could be noted that this measurement did not undergo appreciable alteration. Scavone-Junior $^{13}$ (1996) found the Is-St distance mean values of $2.82 \mathrm{~mm}$ (s.d. $=0.93$ ) and $2.67 \mathrm{~mm}$ (s.d. $=1.07$ ), at 13 years and 6 months and 17 years and 11 months of age, respectively, in patients with satisfactory occlusion and ethnic characteristics similar to those of this study sample. Scavone-Junior et al. ${ }^{12}$ (2003) mentioned that there was a slight and gradual reduction in the Is-St distance, for a sample of patients that had never been treated orthodontically, ratifying the above-mentioned findings.

In this study, it was found that the mean values of the Is-St distance obtained for orthodontically treated patients were increased in comparison with the sample that had satisfactory occlusion (Scavone-Junior ${ }^{13}$, 1996). However, it should be taken into account that this investigation assessed patients with Class II Division 1 malocclusion, a dentoskeletal disharmony related to incompetent lip seal.

Burstone $^{3}$ (1967) reported that the maxillary incisors were shown to be extruded in patients with Class II, Division 1 malocclusion, corroborating this study findings. How then does one explain that the Is-St measurement underwent practically no alteration, if the variable IsPP pointed towards the occurrence of extrusion of the maxillary incisors in relation to their apical base? After joint analysis of the variables Is-St, Is-PP and Sn-St, it was observed that although the maxillary incisors had extruded, there was also a small vertical growth of the upper lip in the group without extractions. In spite of this latter variable $(\mathrm{Sn}-\mathrm{St})$ not having attained a statistically significant modification in the group with extractions, the variation revealed a high standard deviation (Table 1). Therefore, it may be suggested that in many patients vertical lip growth $(\mathrm{Sn}-\mathrm{St}$ ) could have accompanied or even overtaken the extrusion of the maxillary incisors (Is-PP), leading to the maintenance of the incisolabial relationship in the vertical direction (Is-St). Furthermore, the discrete increase in the Is-St distance for the group with extractions was not statistically significant (Table 3).

In patients treated with premolar extractions, although not statistically significant, there was a slight increase in lip height (Sn-St). The pre- and posttreatment mean values for this variable were $22.9 \mathrm{~mm}$ and $23.1 \mathrm{~mm}$, with a mean increase of $0.16 \mathrm{~mm}$ (Table 1). For the group without extractions, the respective values were $21.4 \mathrm{~mm}$ and $22.2 \mathrm{~mm}$, showing a statistically significant mean increase of $0.75 \mathrm{~mm}$ (Table 2). Brant and Siqueira ${ }^{1}$ (2006) observed a similar pre- and posttreatment behavior for this variable, registering a final mean value of $23.9 \mathrm{~mm}$ in the group with extractions and $22.8 \mathrm{~mm}$ in the group without extractions. These data are in agreement with the results obtained by Burstone ${ }^{3}$ (1967), who found an upper lip height value of $20.1 \pm 1.9 \mathrm{~mm}$ in females. Scavone-Junior ${ }^{13}$ (1996) and Talass et al. ${ }^{16}$ (1987) also found no significant increase in the Sn-St measurement.

According to Table 1, in the group with premolar extractions, the vertical distance between the incisal edge of the maxillary incisor and the palatine plane (Is-PP) had a mean increase of $0.71 \mathrm{~mm}(\mathrm{p}<0.01)$, indicating that there was extrusion during the orthodontic treatment and/or growth in height of the alveolar process. Ferraz$z^{4}$ (1997) also found an increase in the Is-PP distance resultant from the orthodontic treatment, corroborating this finding. Moreover, Martins et al. ${ }^{8}$ (1998) similarly observed an increase in the Is-PP distance in individuals aged 12 to 18 years with satisfactory occlusion.

For the group without extractions (Table 2), a mean increase of $1.26 \mathrm{~mm}(\mathrm{p}<0.01)$ was found. It was possible to demonstrate that the vertical distance between the incisal edge of the maxillary incisor and its apical base had a greater mean increase in the group without extractions (Table 3). However, the difference was not statistically significant. The lack of statistical significance between the studied groups may be explained by the proper vertical control during retraction of the maxillary anterior teeth, using adequate application of the gable effect to the orthodontic wire. On the other hand, the group without extractions may have required more intensive use of the intermaxillary elastics, which, in turn, may have caused extrusion of the incisors (Burstone ${ }^{2}$, 1959; Vellini-Ferreira ${ }^{18}$, 2002).

In the group with extractions, there was a significant mean increase of $1.94 \mathrm{~mm}(\mathrm{p}<0.01)$ in the vertical distance between the mesiobuccal cusp of the maxillary first molar and the palatine plane (Ms-PP), indicating that the maxillary molars underwent extrusion. In the group without extractions, it was also found that the maxillary molars underwent extrusion, as the Ms-PP measurement mean increase was of $2.17 \mathrm{~mm}, \mathrm{p}<0.01$ (Table 
Souto M, Maeda PM, Scavone-Junior H, Ferreira RI, Vellini-Ferreira F. Vertical cephalometric changes after treatment of Class II division 1 malocclusion. Revista de Odontologia da Universidade Cidade de São Paulo 2008 jan-abr; 20(1):6-13

2). The extrusion was probably due to alveolar growth and maxilla downward and forward displacement (Vellini-Ferreira ${ }^{18}$, 2002) in association with the extrusive component of the extraoral anchorage (Ferrazzo ${ }^{4}, 1997$; Vellini-Ferreira ${ }^{18}$, 2002). Molar extrusion was observed in patients treated with and without extractions, however, no significant difference was found in the comparison between groups (Table 3).

The clinical importance of this finding is related to the need for care when using extraoral anchorage, which must be prescribed in accordance with the patient's craniofacial growth pattern and the desired movement to the maxillary molars, i.e., intrusion, extrusion or distalization (Ferrazzo ${ }^{4}$, 1997; Scanavini and Vigorito ${ }^{11}$, 1996; Vigorito $\left.^{19}, 1980\right)$.

When comparing the SN.GoMe angle for the two studied groups, pre- and posttreatment, it was demonstrated that this variable presented a similar behavior $(\mathrm{Ta}$ bles 1 and 2). Therefore, it may be inferred that in both groups the initial facial growth pattern was maintained (dolichofacial), evidencing that there was vertical control during the entire treatment. Machado et al. ${ }^{7}$ (2005) and Hans et al. ${ }^{5}$ (2006) also reported proper vertical control by assessing cephalometric pre- and posttreatment data in groups of patients orthodontically treated with and without extractions, since there was no increase in the anterior inferior facial height. Conversely, Martins et al. ${ }^{8}$ (1998) observed that this angle increased, on average by $1.8^{\circ}$, as a result of craniofacial growth from 12 to 18 years of age. Presumably, the SN.GoMe angle demonstrates smaller increases due to orthodontic treatment than in relation to craniofacial growth.

The SN.Gn angle denotes the craniofacial complex growth direction. Based on Tables 1 and 2, this variable increased in both groups, although it had been significant only for those patients treated without extractions. Expectedly, in the same way as SN.GoMe, the SN.Gn angle exhibited a moderate increase between the preand posttreatment stages, ratifying that there was adequate spatial control of the mandible during the entire treatment. Martins et al. ${ }^{8}$ (1998) reported that this angle decreased, on average by $0.8^{\circ}$, from 12 to 18 years of age, demonstrating an inverse behavior compared with that verified for orthodontically treated patients.

Concerning the comparative analyses of the angular variable SN.PP, it was found that, in patients treated with premolar extractions, the palatine plane showed clockwise rotation in relation to the anterior cranial base. Hayashi et al. ${ }^{6}$ (1975) stated that the use of intermaxillary elastics produced clockwise inclination of the palatine plane. Nevertheless, Martins et al. ${ }^{8}$ (1998) also found a mean increase of $2^{\circ}$ in this angle.

Interestingly, the PP.MsIs angle was decreased in both groups, though significant reduction had been demonstrated only for patients treated without extractions (Tables 1 and 2). A possible explanation for this controversial decrease may be found in the analysis of two associated variables: Ms-PP and Is-PP. It appeared that maxillary molars extrusion was greater than maxillary incisors extrusion, thus resulting in an upward inclination of the maxillary occlusal plane.

Based on this study findings, many questions should encourage the development of other investigations. As mentioned by Scavone-Junior ${ }^{13}$ (1996), it would be of great importance to establish cephalometric parameters from research on untreated and treated young patients having similar malocclusions. However, the ethical limitations for this kind of study must be taken into consideration. Furthermore, studies that approach the control of patient's craniofacial growth pattern, particularly related to the vertical type, would be relevant to the current knowledge.

\section{CONCLUSIONS}

According to the results of the present study, it was observed that:

In patients with Class II Division 1 malocclusion submitted to orthodontic treatment with premolar extractions, the variables Is-PP, Ms-PP and SN.PP were shown to be significantly greater in the posttreatment evaluation.

In patients treated without extractions, there was a significant increase in the following cephalometric measurements: Sn-St, Is-PP, Ms-PP and SN.Gn. On the other hand, a significant decrease was found in the inclination of the maxillary functional occlusal plane in relation to the palatine plane (PP.MsIs).

When comparing patients treated with and without premolar extractions, there was statistical difference only for the SN.PP angle, indicating a slightly greater clockwise rotation of the palatine plane in the former group. 


\section{REFERENCES}

1. Brant JCO, Siqueira VCV. Alterações no perfil facial tegumentar, avaliadas em jovens com Classe II, $1^{\text {a }}$ divisão, após o tratamento ortodôntico. Rev Dent Press Ortodon Ortopedi Facial 2006 mar./abr.; 11(2): 93-102.

2. Burstone CJ. Integumental contour and extension patterns. Angle Orthod 1959 Apr.; 29(2): 93-104.

3. Burstone CJ. Lip posture and its significance in treatment planning. Am J Orthod 1967 Apr.; 53(4): 262-84

4. Ferrazzo VA. Estudo cefalométrico radiográfico dos padrões de crescimento facial em pacientes com maloclusões de Classe II, Divisão $1^{a}$ de Angle, tratados ortodonticamente pela técnica do arco de canto. [master thesis] São Paulo: Faculdade de Odontologia da Universidade de São Paulo; 1997.

5. Hans MG, Grossier G, Damon C, Amberman D, Nelson S, Palomo JM. Cephalometric changes in overbite and vertical facial height after removal of 4 first molars or first premolars. Am J Orthod Dentofacial Orthop 2006 Aug.; 130(2): 183-8.

6. Hayashi RK, Chaconas SJ, Caputo AA. Effects of force direction on supporting bone during tooth movement. J Am Dent Assoc 1975 May; 90(5): 1012-7.

7. Machado DT, Henriques JFC, Janson G, Freitas MR. Estudo cefalométrico das alterações das alturas faciais anterior e posterior em pacientes leucodermas, com má oclusão de Classe II, $1^{a}$ divisão de Angle, tratados com e sem extração de quatro primeiros pré-molares. Rev Dent Press Ortodon Ortopedi Facial 2005 jan./fev.; 10(1): 26-41.

8. Martins DR, Janson GRP, Almeida RR, Pinzan A, Henriques JFC, Freitas MR. Atlas de Crescimento. São Paulo: Editora Santos; 1998.

9. Martins LP, Pinto AS, Martins JCR, Mendes AJD. Erro de reprodutibilidade das medidas cefalométricas nas análises de Steiner e de Ricketts, pelo método convencional e pelo método computadorizado. Ortodontia 1995 jan./abr.; 28(1): 4-17.
10. Peck S, Peck L, Kataja M. Some vertical lineaments of lip position. Am J Orthod Dentofacial Orthop 1992 June; 101(6): 519-24.

11. Scanavini JR, Vigorito JW. Avaliação das alterações ortodônticas e ortopédicas resultantes da técnica de arco de canto, aplicada em maloclusões de Classe II Divisão 1. Ortodontia 1996 set./dez.; 29(3): 16-30.

12. Scavone-Junior H, Martins DR, Vellini-Ferreira F, Cotrim-Ferreira FA, Pinzan A, Almeida RR. Avaliação cefalométrica do relacionamento incisolabial vertical, dos 13 aos 18 anos de idade. Rev Odontol UNICID 2003 maio/ago.; 15(3): 183-91.

13. Scavone-Junior H. O perfil facial tegumentar dos 13 aos 18 anos de idade. Estudo cefalométrico longitudinal em jovens brasileiros leucodermas, com oclusão normal. [doctoral thesis] Bauru: Faculdade de Odontologia de Bauru, Universidade de São Paulo; 1996.

14. Subtelny JD. The soft tissue profile, growth and treatment changes. Angle Orthod 1961 Apr.; 31(2): $105-22$.

15. Tadic N, Woods MG. Incisal and soft tissue effects of maxillary premolar extraction in Class II treatment. Angle Orthod 2007 Sept.; 77(5): 808-16.

16. Talass MF, Talass L, Baker RC. Soft-tissue profile changes resulting from retraction of maxillary incisors. Am J Orthod Dentofacial Orthop 1987 May; 91(5): 385-94.

17. Uchiyama LMAF, Pinzan A, Pinzan-Vercelino CRM, Janson G, Freitas MR. Estudo cefalométrico das alturas faciais anterior e posterior, em jovens brasileiros melanodermas, com “oclusão normal". Rev Dent Press Ortodon Ortopedi Facial 2006 nov./dez.; 11(6): 114-29.

18. Vellini-Ferreira F. Ortodontia - Diagnóstico e Planejamento Clínico. $5^{a}$ ed. São Paulo: Artes Médicas; 2002.

19. Vigorito JW. Alguns efeitos do emprego da força extrabucal no tratamento das más oclusões dentárias. Ortodontia 1980 maio/ago.; 13(2): 118-32.

Recebido em: 19/10/2007

Aceito em: 8/12/2007 